\title{
USING VIRTUAL MOBILITY AND DIGITAL STORYTELLING IN BLENDED LEARNING: ANALYSING STUDENTS' EXPERIENCES
}

\author{
Dr. Daniel OTTO \\ Faculty of Humanities and Social Sciences \\ FernUniversitat in Hagen \\ Hagen, Germany
}

\section{ABSTRACT}

The concept of virtual mobility is increasingly receiving attention in the literature. As one central advantage, virtual mobility enables international and intercultural experiences for non-traditional students regularly found in distance education. However, hitherto there is a lack of empirical data on the students' experiences with virtual mobility. Moreover, adequate teaching methods and course designs have to be identified which stimulate the students' learning motivation and learning success. This article addresses these challenges by presenting results from a joint blended learning course of two distance universities. Constructive alignment was used to implement virtual mobility and digital storytelling. The evaluation of the course demonstrates that the students generally value the opportunity for virtual mobility but likewise appreciate face-to-face contact. It also stresses the importance of suitable teaching methods and adequate course designs to spur the students' collaboration and to achieve the intended learning outcomes.

Keywords: Virtual mobility, distance education, blended learning, digital storytelling, distance learning, constructive alignment.

\section{INTRODUCTION}

Over a long period, student mobility was treated as equal with the actual exchange of place of study. The primary goal of this exchange has been to enhance professional and intercultural competences (Harry, 1999; Messer \& Wolter, 2007; Sowa, 2002). In the course of the digitalisation of university teaching, the concept of virtual mobility has brought fresh impetus to the debate revolving around new opportunities for the student exchange without changing the place of study. While several definitions of virtual mobility exist (see for an overview Tereseviciene, Margarita Volungeviciene \& Dauksiene, 2011), they are all rooted in the basic idea that virtual mobility "offers access to course and study schemes in a foreign country and allows for communication activities with teachers and fellow students abroad via the information and communication technologies" (Brey, 2007). Hence, virtual mobility can play an important role in pursuing the bologna goals according to which increasing mobility is considered to be a key factor. Scholars in distance education have criticised that virtual mobility is not adequately considered given the important leverage it has to increase the mobility of students in an effective and innovative way (Schreurs, Michielsens, Verjans, \& Van Petegem, 2006). Studies about best practices and pilot projects in Europe demonstrate the manifold opportunities for virtual mobility (Op de Beeck \& Van Petegem, 2013; Schreurs et al., 2006; Vriens, Petegem, \& Achten, 2010).

In this article, the potential of virtual mobility is acknowledged by asserting that especially non-traditional students in distance education with limited opportunities for longer periods of physical mobility can benefit from the international and intercultural experiences made possible through the latest information and communication technology (ICT). This is based 
on the dominant perception in the literature, stating that virtual mobility can establish new learning opportunities by either using it alternatively or complementary to the idea of physical exchange (Otto, 2014; Schreurs et al., 2006; Wende, 1998). Complementary under this premise means the suitable integration of phases of virtual mobility in blended learning approaches. While blended learning combines face-to-face instructions with computer mediated instruction (Bonk \& Graham, 2005), virtual mobility in this manner is understood as an opportunity for non-traditional students that predominantly form the target group in distance education (Jahng, Krug, \& Zhang, 2007). These students are henceforth excluded from longer periods of physical exchange due to their spatial and time restrictions. In blended learning approaches, virtual mobility can serve as an opportunity for these students to collaborate with fellow students from abroad.

While exclusive usage of virtual mobility can be identified in the literature (de Kraker \& Corvers, 2014), incorporating it in blended learning approaches might be of advantage as it allows physical encounter and thereby increases the commitment between the participants, thus minimizing the free rider problem (Matzat, 2013). In general terms, blended learning appears favourable as it unites the advantages of virtual and physical mobility (Matzat, 2013; Op de Beeck \& Van Petegem, 2013). However, solely using innovative digital tools for virtual mobility does not guarantee convincing learning results (Op de Beeck \& Van Petegem, 2013; Vriens et al., 2010). Especially if the objective is to implement virtual mobility in blended learning approaches, choosing suitable teaching methods and course designs is essential to establish a productive learning atmosphere and to achieve the intended learning outcomes (Kenney \& Newcombe, 2011; Means, Toyama, Murphy, \& Baki, 2013).

Despite the potential benefits that exist for the use of virtual mobility in blended learning approaches, there still is little empirical data to support this claim (Op de Beeck \& Van Petegem, 2013). In this article, it is argued that a promising approach for the empirical verification is to bring in the students' perspectives. The guiding research question therefore is how students assess their experiences with virtual mobility in blended learning approaches. Derived from this research question the assumption will be examined that the choice of a suitable teaching method and the corresponding course design plays a key role for the learning atmosphere and the learning success.

In order to test this assumption and to answer the research question, results from a joint course of two distance universities are presented that implemented virtual mobility in a blended learning approach. Based on Biggs model of constructive alignment (Biggs, 2003), digital storytelling was applied in the course design to achieve the intended learning outcomes. digital storytelling as a project-based-learning (PL) is a constructivist teaching method and a student-centered approach (Gibbs, 1981; Robin, 2016). The main intention was that this collaborative teaching method would spur intercultural exchange and intercultural learning during the periods of virtual mobility and the face-to-face meetings.

As for the structure of the article, in the second section the courses design and the manner in which virtual mobility was integrated are described. In the third section, the methodological approach is outlined. In the fourth section, the results of the analysis are presented. This encompasses the students' experiences with virtual mobility and digital storytelling. For section five this allows to inductively answer the initial research question and to draw some conclusions about the benefits of virtual mobility in blended learning approaches as well as the influence of the teaching method on the overall learning success.

\section{COURSE DESIGN}

Albeit the discussions about virtual mobility are in full swing, they are cohesive in their fundamental aim to facilitate intercultural and professional collaboration between students and staff based on the latest use of ICT (Tereseviciene, Volungeviciene, \& Dauksiene, 2013). In order to achieve these goals, it is crucial to select a suitable teaching method and 
the respective courses design. These choices should not be erratic but consistent with the intended learning outcomes.

For the course design, Biggs principles of constructive alignment were applied (Biggs, 2003). Rooted in constructivist learning theories, constructive alignment favours outcomebased teaching and learning instead of merely conveying content to the students (Biggs, 1996, 2012). Learners are perceived as the active creators of knowledge and meaning. Teachers organise and structure the teaching and learning contexts of the students acting as facilitators that guide the learners to achieve learning compatibility with their previous experiences, individual intentions, or motives. Following constructive learning principles, learners are dynamically selecting and constructing knowledge through individual and social activity (Biggs, 1996; Piaget, 1968, 1980).

Against this background, the course design and teaching method were selected to spur student collaboration and engagement, which, according to the literature, is supposed to result in higher learning success (Otto, 2017; Wang, Su, Cheung, Wong, \& Kwong, 2013). The following course was offered in two distance education Master programme which are focusing on interdisciplinary topics in environmental sciences. The curricula do not encompass opportunities for students to participate in long-term mobility programmes. The course was therefore intended to enable international and intercultural experiences for the students by combining short periods of physical exchange with longer periods of virtual collaboration. Participation should result in valuable professional and intercultural experiences. The course received full funding from the German Academic Exchange Service (DAAD), which is financed by the German Ministry of Foreign Affairs.

In total, the duration of the course was about three months. In terms of accreditation and workload, the course encompassed two five days workshops and was awarded with 5 ECTSpoints equal to 150 working hours.

The objectives for the course encompassed to:

$>$ establish a common knowledge ground by considering the previous knowledge and disciplinary background of the students

$>$ develop and implement adequate learning methods to facilitate students learning

$>$ design the course in a way that the intended learning outcomes are achieved

For the implementation of the course design, all these different components have to become aligned (Biggs, 1996).

\begin{tabular}{|c|c|}
\hline Course approach & Interdisciplinary \\
\hline Partner & German and Tunisian \\
\hline Main learning objectives & $\begin{array}{l}\text { Understanding climate change in an intercultural } \\
\text { perspective }\end{array}$ \\
\hline Teaching method & Digital storytelling \\
\hline Duration & 3 month \\
\hline Format & Blended Learning \\
\hline Credit & 5 ECTS (150 working hours) \\
\hline $\begin{array}{l}\text { Blended learning } \\
\text { approach }\end{array}$ & \\
\hline
\end{tabular}

Figure 1. Course Design

As shown in the table, the course addressed the topic of climate change, which is a key topic in the curricula of the participating universities. In terms of content, climate change can be characterized as a super wicked problem entailing complex interdependencies that 
make it impossible to be addressed without massive economic and social consequences (Lazarus, 2009; Levin, Cashore, Bernstein, \& Auld, 2012). Therefore climate change can be perceived as a challenge which requires an interdisciplinary approach to understand all its dimensions and the interwoven consequences (Hulme, 2009). The impacts of climate change can only be understood by adopting a global perspective that critically reflects individuals' actions and their underlying conceptions of the world (Abbott \& Wilson, 2015).

Based on the principles of constructive aliment, common learning objectives were identified that all students ought to achieve after they completed the course:

$>$ understand climate change from an interdisciplinary perspective;

$>$ critically reflect the own individuals' actions towards climate change and their underlying conceptions of the world;

$>$ analyse and communicate the problem of climate change.

For the course design, Biggs four steps for constructive alignment were applied (Biggs, 2003):

$>$ Defining the intended learning outcomes (ILOs);

$>$ Choosing teaching/learning activities likely to lead to the ILOs;

$>$ Assessing students' actual learning outcomes to see how well they match what was intended;

$>$ Arriving at a final grade.

\section{CASE STUDY}

The course was an interdisciplinary co-operation between a German and a Tunisian distance university that brought together distance students from various academic disciplines to study a course about climate change. The students can be regarded as nontraditional because they varied in age, studied part-time, already worked, had children and some were single parents. Against the backgrounds of the students' heterogeneity in academic, cultural and professional terms, the intended learning outcomes were that students could:

$>$ describe and research climate change as an interdisciplinary topic;

$>$ recognise the different cultural understandings of climate change;

$>$ compare and contrast different lived experiences of climate change from a global perspective; and

$>$ reflect critically on their own cultural perspective regarding climate change.

In the second step, digital storytelling was chosen as a teaching method that would obtain the intended learning outcomes. Digital storytelling is a teaching method that has emerged as a powerful teaching and learning method in the last decade (Robin, 2008; Robin \& McNeil, 2012). It is a nexus of traditional storytelling combined with the use of the latest ICT. Albeit the tradition of storytelling used to convey knowledge to recipients in a meaningful and lively manner is ancient, its use in formal higher education teaching solely started in the beginning of the 1990s (Egan, 1989).

For the course, digital storytelling was considered favourable for the intended learning outcomes for the following reasons:

$>$ Digital storytelling is a student-centered learning approach. The aim is to research and collaborate in small groups to produce a short, appealing and likewise instructive story no longer than three to five minutes. The teachers assist and act as facilitators in this process (Robin \& McNeil, 2012).

$>$ Storytelling is used in higher education to explain complex problems (Chisholm \& Trent, 2013; Gubrium \& Scott, 2010; Gubrium \& Turner, 2011); in our case, the 
wicked problem of climate change (Lazarus, 2009; Levin et al., 2012). Digital storytelling makes lived experiences coherent with academic knowledge to capture the audience's attention. Facts are embedded into an emotional and appealing narrative.

$>$ PL digital storytelling encourages student groups to select a climate changerelated topic that merges their different disciplinary along with their academic and personal interests.

$>$ As an instrument for deep learning, engagement and reflection (Barrett, 2016), digital storytelling emboldens the students to critically reflect their own cultural understanding of climate change.

$>$ As the digital stories are shared, presented and discussed at the end of the course, they help the students to compare and contrast different lived experiences of climate change.

Beside the core intended learning outcomes, it was recognised the advantage that digital storytelling:

$>$ Enhances technology competence as it teaches the practise and use of new ICT to compose and share stories (Robin, 2006).

$>$ Can be implemented at low costs as it solely requires the possession of mobile devices with cameras, free video editing software, and computers to create and share the digital stories (Meadows, 2003).

In a nutshell, digital storytelling offers a suitable teaching method to accomplish the intended learning outcomes by researching, analysing and reflecting complex problems, collaborate in groups and practise student-centered learning based on PL, which thus encourages interdisciplinary and intercultural learning. For the course design and against the background of constructive alignment, learning activities and formative and summative assessment had to be implemented to allow students to achieve our intended learning outcomes.

Recurring to the aforementioned didactical, theoretical and methodical considerations following course design was used:

\begin{tabular}{|c|c|c|c|c|}
\hline \multicolumn{5}{|l|}{ Course structure } \\
\hline & Learning activities & $\begin{array}{l}\text { Summative } \\
\text { feedback }\end{array}$ & Assessment & Duration \\
\hline $\begin{array}{l}\text { Online Preparation } \\
\text { Phase (learning } \\
\text { platform) }\end{array}$ & $\begin{array}{l}\text { - Introduce to others } \\
\text { course members } \\
\text { and tutors } \\
\text { Study the concept } \\
\text { of the lived } \\
\text { experience }\end{array}$ & $\begin{array}{l}\text { feedback from } \\
\text { tutors }\end{array}$ & & 1 month \\
\hline $\begin{array}{l}\text { Workshop Phase } \\
\text { (physical encounter } \\
\text { in Germany) }\end{array}$ & 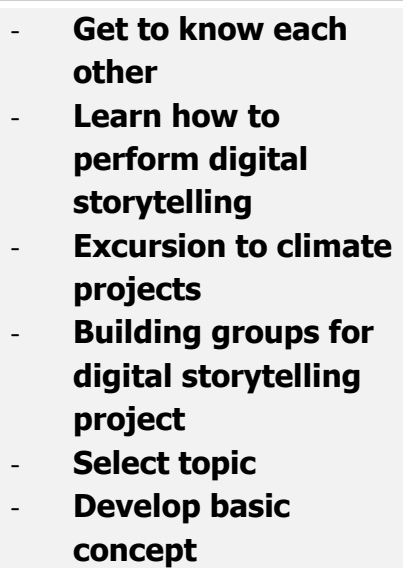 & $\begin{array}{l}\text { Providing } \\
\text { information and } \\
\text { guidance for } \\
\text { composing digital } \\
\text { story }\end{array}$ & & 5 days \\
\hline
\end{tabular}




\begin{tabular}{|c|c|c|c|c|}
\hline $\begin{array}{l}\text { Online } \\
\text { Implementation } \\
\text { Phase }\end{array}$ & $\begin{array}{ll}\text { - } & \text { Virtual } \\
& \text { collaboration } \\
\text { - } & \text { Develop script and } \\
\text { storyboard } \\
\text { - } & \text { collect material }\end{array}$ & $\begin{array}{l}\text { Providing } \\
\text { assistance }\end{array}$ & $\begin{array}{l}\text { Written } \\
\text { assessment of } \\
\text { storyboard }\end{array}$ & $\begin{array}{l}2 \\
\text { months }\end{array}$ \\
\hline $\begin{array}{l}\text { Workshop Phase } \\
\text { (Tunisia) }\end{array}$ & $\begin{array}{ll}\text { - } & \text { Finalize digital story } \\
\text { - } & \text { Excursion to climate } \\
\text { projects } \\
\text { - } \quad \text { Present and discuss } \\
\text { digital story with } \\
\text { others }\end{array}$ & $\begin{array}{l}\text { Providing } \\
\text { assistance } \\
\text { Discuss } \\
\text { presentations and } \\
\text { give feedback } \\
\text { Open debate with } \\
\text { students on } \\
\text { experiences with } \\
\text { course }\end{array}$ & $\begin{array}{l}\text { Oral } \\
\text { assessment of } \\
\text { digital story }\end{array}$ & 5 days \\
\hline Reflection Phase & $\begin{array}{l}\text { - Writing individual } \\
\text { reflection report } \\
\text { about experiences } \\
\text { with the course }\end{array}$ & $\begin{array}{l}\text { Qualitative } \\
\text { feedback on } \\
\text { individual reflection } \\
\text { reports }\end{array}$ & $\begin{array}{l}\text { Formal } \\
\text { assessment of } \\
\text { digital story }\end{array}$ & 2 weeks \\
\hline
\end{tabular}

Figure 2. Course Structure

To deepen the learning experience during the course and to critically examine their own role, all students were required to write an individual reflection report (three to five pages) at the end of the course in which they reflected on their overall experiences and learning outcomes. The use of individual reflection reports is inspired by Petranek's concept of written debriefing, which can be understood "as an experiential activity in which participants have the opportunity to write about their experiences and feelings and those of others" (Petranek, 2000). Reminiscing about and re-enacting the various situations that occurred during the learning process can spur a deeper understanding of individual learning and help participants scrutinize self-perception in this process. In an intercultural and collaborative learning setting, this process is intensified even further by the diversity of impressions. While reflection reports lack a clear structure, teachers provide some guidance in the form of a list comprising broader categories, for instance, educational approach, intercultural experience, learning outcomes, group work dynamics or blended learning.

\section{METHOD}

The method of evaluation was intended to render the students' experiences and perceptions about virtual mobility and the blended learning approach. Moreover, it should disclose to what extent digital storytelling was feasible to reach the intended learning outcomes and spur intercultural and professional exchange.

The content-related focus was on the individual reflection reports the students had to hand in at the end of the course. The author considers individual reflection reports to be a valuable source to delve deeper into the learning experience of the students as they allow the students to set their own personal focus and priorities. Additionally, they permit a more frank and open discussion than oral debriefing in a group or a direct communication with the tutors (Petranek, 2000). Nonetheless, it is acknowledged that the non-linear structure of the reports makes it more difficult to evaluate them than for example questionnaires. However, the deepness and profundity of the findings are worth a more multifaceted evaluation. To align and verify the students' perceptions and that of the teachers, participatory observations of the teachers were used during the course. The author of this article was part of the group of teachers that initiated, planned and implemented the course. 


\section{Participants}

The course was offered two times. In total, 46 students participated. As already described, the students can be regarded as non-traditional as they significantly varied in age, academic background. Moreover, they were studying part-time, already working, have children and some are a single parent.

Table 1. Participants of the Course

\begin{tabular}{llllll}
\hline Course & Students & Nationality & & Gender & \\
\hline First course & 26 & 12 German & 13 Tunisian & 9 male & 17 female \\
Second course & 20 & 11 German & 11 Tunisian & 6 male & 14 female \\
\hline
\end{tabular}

Data Collection and Analysis

In terms of data evaluation, qualitative methods were applied to code and cluster the results. The qualitative evaluation was complemented by the participative observation to align students' perception with the teachers' impression during the course. The reflection reports were coded using Mayring's structured qualitative content analysis (Mayring, 2000) and MAXQDA, which is qualitative and mixed methods data analysis software. Structured content analysis works with "prior formulated, theoretical derived aspects of analysis, bringing them in connection with the text" (Mayring, 2000). The first set of deductive categories was derived from the research question about the students' perception of virtual mobility and blended learning. To render the students' experiences with the teaching method, the broader theoretical categories of digital storytelling and related aspects were applied to carve out in which context they appeared in the reflection reports.

To secure reliability and reproducibility of the results, the first coding of the reflection reports was done by researchers who were not involved in the course. A second coding for verification and quality inspection was conducted by the author of this article. The subcategories and statements presented in the next section are results of the coding. These results were merged with the participatory observation of the teachers. The selected quotes of the students were chosen as they are representative for the results of the broader analysis.

\section{FINDINGS}

In an overall perspective, the evaluation of the reflection reports and the participatory observation disclosed that all students had positive experiences and learning success. This is supported by the fact that there were no drop-outs during the course and that all groups managed to submit a final product. Furthermore, $\mathbf{3 8}$ of the $\mathbf{4 6}$ students that participated handed in their individual reflection report.

\section{Virtual Mobility}

Non-traditional students in distance education are usually higher in age than university students and mostly work part or full-time (Carr, 2000). This might be decisive for three categories that were salient in the reflection report in terms of virtual mobility.

\section{Technology Competence}

As a first finding, the added value of the online tools provided for collaboration during the course was highlighted by the students. Likewise, using these tools appears to have significantly improved the students' technology skills and competences. While basic skills and competences to use ICT are necessary for distance students, using new online tools like Adobe Connect, Google Docs or Colibri was indicated positively by the students. As one German student stated:

"I intensified my skill on how to divide work in a group, especially in a virtual one. The tools of Skype and Google document greatly helped with that." 
Technology competences strongly varied across the course members. While some were already familiar or experienced with most of the tools, for others Adobe Connect was a totally new experience. A student indicated in her reflection report:

"I have a lot of experience with online courses but the Kick-Off Meeting was my personal premiere for use of Adobe Connect with microphone and camera. I will profit from this experience during my further studies."

Noteworthy, if misbalances in skills and experiences in the use of ICT occurred, the students were able to cope with this in their groups by helping each other like a German student explained:

"I learned a lot - thanks to my fellow students - not only about video cutting with iMovie and Powerdirector, but also about working with Skype and Dropbox. (...) it was the first time that I really felt responsible for organising and chairing videoconferences. This was a good experience for me."

Findings from the reflection reports and the participatory observation persuasively demonstrated that collaboration was possible not only in physical meetings. As a German student exemplarily stated:

"We learned that it is possible to collaborate and create something of relevance to the world almost solely using virtual means of communication."

\section{Autonomy and Self-regulated Learning}

Another salient finding from the participatory observation and the reflection reports was that the blended learning approach with longer phases of virtual mobility complied with the students' requirement to learn and collaborate autonomously and self-determined. Overall, the students appreciated the opportunity to meet and exchange with others virtually and physically. A student exemplarily said that:

"I personally find it crucial to have such possibilities where you can meet other students, get to know them and their backgrounds and motivation for - in our case - environmental sciences, but also to work together, discuss content and exchange experiences and views."

Again, this is the case for non-traditional students in distance education that need a higher flexibility because of their diverse personal circumstances. For instance, a German student described that virtual learning allowed him to make self-regulated decisions about when and where he wanted to learn:

"Virtual learning is a wonderful way for me to deal with new tasks. I'm independent of fixed learning sessions and can freely decide when and where I learn."

Virtual mobility can therefore serve as an ideal way for these students to gain international and intercultural experience. Perceived as an opportunity, it enables students to collaborate and exchange with others across boundaries such as countries and languages. Self-determined learning, on the one hand, and to collaborate with others, on the other hand, appears thus not to be contradictious but reconcilable. A Tunisian student described how her group was motivated to share ideas and experiences with each other. This yielded in improved skills and triggered mutual learning. Obviously, the use of technology facilitated this process: 
"I was also motivated to talk about my experiences with other members in the group, and I enjoyed sharing ideas and learning from each other; in this sense, virtual work and the use of technology facilitated the process a lot."

\section{Face-to-face Interaction}

Despite the fact that the experiences with virtual mobility and virtual learning were perceived as valuable, the evaluation points to the importance of physical meetings, even if only for a few days. The results of the reflection reports underpin the findings from the literature that face-to-face meetings enhance trust as well as reliability and thus minimize the free rider problem. The workshops were described as the most stimulating experience by the majority of the students. For example, a German student mentioned the encouragement of having such a workshop and its importance for long-lasting learning effects:

"The workshops were good to meet each other, build up mutual commitments and a common knowledge base. The workshops functioned as a starting point for the collaborative online learning."

Especially for students in distance education, such courses are an opportunity to overcome the often deprecated isolation:

"To me the seminar was the absolute highlight during my studies and I would wish for any student to get the chance of doing this towards the end. It was possible to work closely with the coordinators and also to build up a personal connection, which is sometimes missed within the distance learning."

This statement strengthens the argument that virtual mobility can complement but not entirely replace physical exchange. Although virtual mobility can generate valuable experiences, it cannot substitute face-to-face interaction, particularly if the collaboration is cross-cultural. Students' encounter encourages a common group spirit and facilitates familiarity. However, replacing the first or second workshop with a virtual meeting to get to know each other could be considered as future options.

To deduce whether purely online seminars might have produced similar outcomes is hypothetical and can only be answered counterfactually. An online kick-off meeting could putatively have analogous effects. Notwithstanding these analogous effects, the student reflection reports indicate that the workshops constituted a salient part of the overall experience.

\section{Teaching Method}

The evaluation of the reflection reports was intended to determine to what extent the learning method, embedded in a blended learning approach, contributed to the collaboration and engagement of the students, the learning atmosphere and the learning success in terms of the intended learning outcomes.

\section{Digital Storytelling}

The overall results of the coding of the reflection reports (Table 2) disclose that implementing digital storytelling in the course design managed to develop the competences previously identified in the literature:

Table 2. Binary Coding of Broader Categories in The Reflection Reports Per Student (N38)

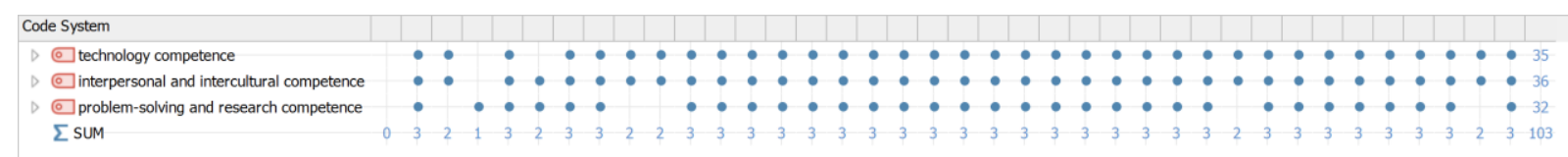


Technology competence (n35) was obtained through the application of ICT to collect and compose the digital story. Competence development was enhanced due to the fact that during the virtual learning, exchange of ideas and data had to be realized using digital tools and software.

Interpersonal and intercultural competence (n36) was developed through online groupbased working and the presentation of the digital story to other groups. The groups indicated that during the online phase they managed to distribute the work and share responsibilities. This likewise entails acceptance of different working and communication styles during the group work. Building consensus among group members resulted in a higher acceptance of individual tasks and thus better outcomes.

Problem-solving and research competences (n38) Research competences were demonstrated as all of the groups submitted satisfying academic problems of climate change for their storyboards. In the next step, they were able to transform this climate change-related scientific topic into a digital story. Problem-solving competence was indicated by the vast majority of students as they were able to manage their individual and group-based learning pathways. For collecting the material and developing a storyboard, group coordination was compulsory. When problems arose, they had to be tackled through self-regulation in the group.

The qualitative evaluation was furthermore expected to reveal whether the alignment of learning outcomes and digital storytelling as a learning method resulted in perceived learning success of the students.

Table 3. Coding of Subcategories in The Reflection Reports Per Student (N38)

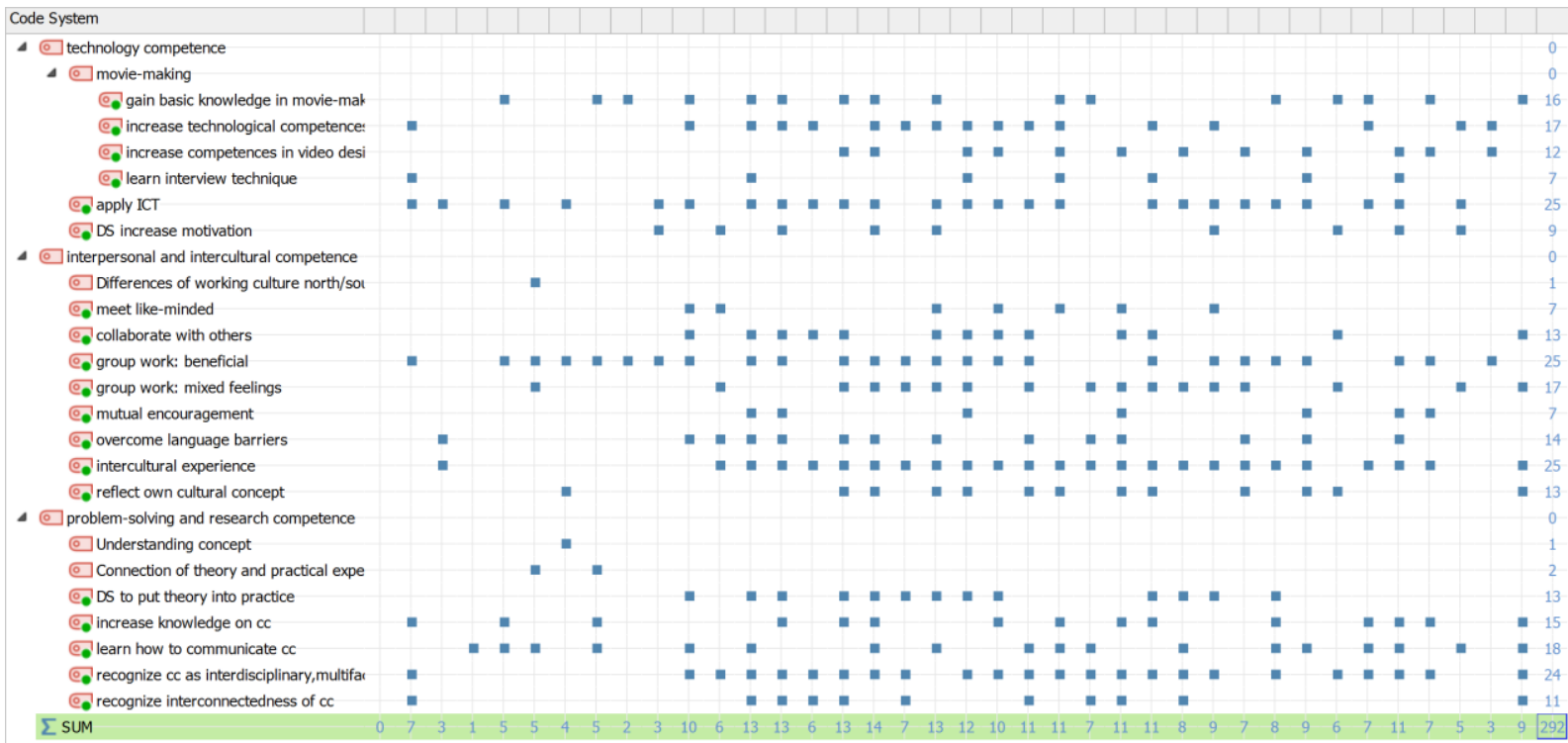

The subcategories that were coded for the three broader categories in the reflection reports (Table 3) show that several skills and competences have improved during the course. Obviously, digital storytelling as PL unveiled the interdisciplinarity (n24) and interconnectedness (n11) of climate change as, in our case, a wicked problem. For example a German student mentioned:

"I have learned that the way climate change is perceived and experienced has a significant effect on lifestyle on a small scale as well as politics and mitigation on a large scale." 
The group work was predominantly perceived a beneficial (n25) and as a chance to meet and collaborate with others. Academic knowledge about climate change was expanded by the lived experiences in both countries in the process to put the digital story into practice (n13). In the process of digital storytelling, the group members were encouraged to choose a climate change related topic and to reconcile their different disciplinary as well as their academic backgrounds and personal interests.

This process also strengthened soft-skills, cope with language (n14) and intercultural barriers and triggered to reflect the own cultural concept (n13). As a German student expressed:

\begin{abstract}
"For me, learning that apart from the academic and scientific way of analysing and depicting the climate change there is a concept that involves and researches non-academic experiences, opinions and views was learning a whole new perspective."
\end{abstract}

In a nutshell, digital storytelling for the case of climate change served as an instrument for deep learning, engagement and reflection.

\title{
CONCLUSION
}

Virtual mobility in blended learning can be a valuable learning experience for nontraditional students in distance education. The results presented also corroborate the assumption that a stimulating teaching method, embedded in a suitable course design, is crucial for the learning success of the students.

Notwithstanding that pure virtual mobility can be a valuable experience in itself; the results of the evaluation indicate that a mixture in the form of blended learning appears to be the preferable choice for non-traditional students in distance education. According to this understanding, virtual mobility is then used complementary and not as a compensation for physical exchange. Non-traditional students for which typical exchange programmes are predominantly incompatible can thus benefit from a combination of short physical and longer periods of virtual exchange. As elucidated, while one physical encounter might potentially be sufficient, this should not lead to the assumption that physical encounter in general is superfluous.

Another key finding from the analysis is the importance of a careful alignment of teaching method and course design for virtual mobility in blended learning approaches. The results of the evaluation disclose that amalgamating the different components can elicit the students learning success and ameliorate their intercultural and professional skills and competences. Increased technology competences appear to be one major outcome as a result of the successful implementation of virtual mobility.

As constructive alignment advises, preferences for teaching method and course design must be intentional, not arbitrary. Intended learning outcomes have to be aligned with course design and the teaching method. In the case presented, constructive alignment demonstrated to be a promising concept. As a salient observation, students' self-regulation instead of teacher-centred approaches in digital storytelling proved to be extremely advantageous for intercultural experiences. Careful mediation by teachers to facilitate the learning process is nonetheless strongly recommended. Despite the fact that digital storytelling was consistent with the learning outcomes about climate change, it might be incongruous in other educational contexts. In this regard, more research is needed. 
To sum up, virtual mobility in blended learning that takes advantage of both, physical and virtual exchange appears to be a practical way for distance education. This amalgamation can empower a broad range of non-traditional students in distance but also in conventional universities to benefit from the internationalisation of university teaching.

For the solidification and generalisation of these inductive findings, more case studies are needed to harden the empirical ground.

ACKNOWLEDGEMENTS: For the development and implementation of the course, full funding was received from the German Academic Exchange Service (DAAD), which is financed by the German Ministry of Foreign Affairs. The author would like to thank the Tunisian partner and a number of individuals who have contributed to the course, including Sara Becker, Kirsten Sander and most importantly, all the students who participated in the course.

\section{BIODATA and CONTACT ADDRESSES of AUTHOR}

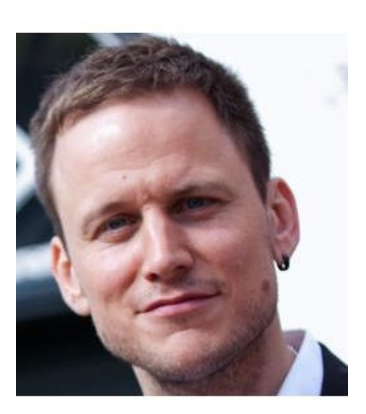

Dr. Daniel OTTO is a research assistant at the chair of International Politics at the FernUniversitat in Hagen. In addition, he is a lecturer for the further studies program Interdisciplinary Distance Studies of Environmental Sciences. He received his PhD from the Goethe University in Frankfurt. He holds a Master's degree from the University of Tübingen and a Bachelor degree from the University of Rostock. His research interests are international climate change politics as well as learning innovations in distance teaching and blended learning. In his current research projects, he is investigating the effects of MOOCs, peer-assessment and digital storytelling on students' learning.

\section{Daniel OTTO}

Department of Political Science

Faculty of Humanities and Social Sciences, FernUniversitat in Hagen

Universitatsstraße 33, 58097, Hagen, Germany

Phone: +49 23319872597

E-Mail: daniel.otto@fernuni-hagen.de

\section{REFERENCES}

Abbott, D., \& Wilson, G. (2015). The Lived Experience of Climate Change. Knowledge, Science and Public Action. Cham, CH: Springer International Publishing.

Barrett, H. C. (2016). Researching and evaluating digital storytelling as a deep learning tool. Proceedings of Society for Information Technology \& Teacher Education International Conference, 647-654.

Biggs, J. (1996). Enhancing teaching through constructive alignment. Higher Education, 32(3), 347-364. doi:10.1007/BF00138871

Biggs, J. (2003). Aligning teaching for constructing learning. The Higher Education Academy, 94(11), 4. doi:10.1063/1.3100776

Biggs, J. (2012). What the student does: teaching for enhanced learning. Higher Education Research \& Development, 31(1), 39-55. doi:10.1080/07294360.2012.642839

Bonk, C. J., \& Graham, C. R. (2005). The handbook of blended learning : global perspectives, local designs. Pfeiffer.

Brey, C. (2007). Guide to Virtual Mobility. Retrieved from http://145.20.178.4/Portals/0/documents/The_Guide_to_Virtual_Mobility.pdf 
Carr, S. (2000). As distance education comes of age, the challenge is keeping the students. Chronicle of Higher Education, 46(23), 39-41.

Chisholm, J. S., \& Trent, B. (2013). Digital Storytelling in a Place-Based Composition Course. Journal of Adolescent \& Adult Literacy, 57(4), 307-318. doi:10.1002/jaal.244

de Kraker, J., \& Corvers, R. (2014). European Virtual Seminar on Sustainable Development: international, multi-disciplinary learning in an online social network. In U. M. Azeiteiro, W. Leal Filho, \& S. Caeiro (Eds.), E-Learning and Education for Sustainability (pp. 117-136). Frankfurt a. M. [u.a.]: Peter Lang.

Gibbs, G. (1981). Teaching Students to Learn: A Student-Centered Approach. The Open University, 12 Cofferidge Close, Stony Stratford, Milton Keynes MK11 1BY, England (\$3.95).

Gubrium, A., \& Scott, T. (2010). Teaching and Speaking to Social Change: A Digital Storytelling Approach Addressing Access to Higher Education. Societies Without Borders, 5(2), 126-151.

Gubrium, A., \& Turner, K. C. N. (2011). Digital Storytelling as an Emergent Method for Social Research and Practice. In S. N. Hess-Biber (Ed.), Handbook of Emergent Technologies in Social Research (pp. 469-491). Oxford: Oxford University Press.

Harry, K. (1999, February 25). Higher Education Through Open and Distance Learning. Routledge. doi:doi:10.4324/9780203018569

Hulme, M. (2009). Why We Disagree About Climate Change: Understanding Controversy, Inaction and Opportunity. Cambridge: Cambridge University Press.

Jahng, N., Krug, D., \& Zhang, Z. (2007). Student achievement in online distance education compared to face-to-face education. European Journal of Open, Distance and ELearning, 10(1), 1-16.

Kenney, J., \& Newcombe, E. (2011). Adopting a blended learning approach: Challenges encountered and lessons learned in an action research study. Journal of Asynchronous Learning Network, 15(1), 45-57. doi:10.1016/j.sbspro.2014.01.992

Lazarus, R. J. (2009). Super wicked problems and climate change: Restraining the present to liberate the future. Cornell Law Review, 94(5), 1153-1233.

Levin, K., Cashore, B., Bernstein, S., \& Auld, G. (2012). Overcoming the Tragedy of Super Wicked Problems: Constraining Our Future Selves to Ameliorate Global Climate Change. Policy Sciences, 45(2), 123-152. doi:10.1007/s11077-012-9151-0

Matzat, U. (2013). Do blended virtual learning communities enhance teachers' professional development more than purely virtual ones? A large scale empirical comparison. Computers and Education, 60(1), 40-51. doi:10.1016/j.compedu.2012.08.006

Mayring, P. (2000). Qualitative Content Analysis. Forum: Qualitative Social Research: Qualitative Methods in Various Disciplines I: Psychology, 1(2), 1-10.

Meadows, D. (2003). Digital Storytelling: Research-based Practice. New Media Visual Communication, 2(2), 189-193.

Means, B., Toyama, Y., Murphy, R., \& Baki, M. (2013). The Effectiveness of Online and Blended Learning: A Meta-Analysis of the Empirical Literature. Teachers College Record, 115(30303), 1-47.

Messer, D., \& Wolter, S. (2007). Are student exchange programs worth it? Higher Education, 54(5), 647-663. doi:10.1007/s10734-006-9016-6 
Op de Beeck, I., \& Van Petegem, W. (2013). Virtual mobility: An alternative or complement to physical mobility? In ERACON 2011 \& 2012 Dual Year Proceedings (pp. 151-160). Cluj-Napoca, Romania .

Otto, D. (2014). Studentischer Austausch in der Fernlehre? A digital story! In O. ZawackiRichter, D. Kergel, N. Kleinefeld, P. Muckel, J. Stöter, \& K. Brinkmann (Eds.), Teaching Trends 2014 (pp. 137-152). Münster: Waxman Verlag.

Otto, D. (2017). Students' interaction for enhancing learning motivation and learning success: findings from integrating a simulation game into a university course. In L. Gómez Chova, A. López Martínez, \& I. Candel Torres (Eds.), International Technology, Education and Development Conference (pp. 1316-1324). Barcelona, Spain: IATED Academy. doi:10.21125/inted.2017.0045

Petranek, C. F. (2000). Written Debriefing: The Next Vital Step in Learning with Simulations. Simulation \& Gaming, 31(1), 108-118. doi:10.1177/104687810003100111

Piaget, J. (1968). Genetic Epistemology. New York [u.a.]: Columbia University Press.

Piaget, J. (1980). Strukturalismus. Stuttgart: Klett-Cotta.

Robin, B. (2006). The Educational Uses of Digital Storytelling. In C. M. Crawford, R. Carlsen, K. McFerrin, J. Price, R. Weber, \& D. A. Willis (Eds.), Proceedings of Society for Information Technology \& Teacher Education International Conference 2006 (pp. 709-716). Orlando, Florida, USA: Association for the Advancement of Computing in Education (AACE).

Robin, B. (2008). Digital Storytelling: A Powerful Technology Tool for the 21st Century Classroom. Theory Into Practice, 4ᄌ(3), 220-228. doi:10.1080/00405840802153916

Robin, B. (2016). The power of digital storytelling to support teaching and learning. Digital Education Review, (30), 17-29.

Robin, B., \& McNeil, S. G. (2012). What educators should know about teaching digital storytelling. Digital Education Review, 22, 37-51.

Schreurs, B., Michielsens, C., Verjans, S., \& Van Petegem, W. (2006). Towards sustainable virtual mobility in higher education institutions.

Sowa, P. A. (2002). How valuable are student exchange programs? New Directions for Higher Education, 2002(117), 63-70. doi:10.1002/he.49

Tereseviciene, Margarita Volungeviciene, A., \& Dauksiene, E. (2011). Curriculum design for virtual mobility - significance of teacher-student interaction. Kaunas.

Tereseviciene, M., Volungeviciene, A., \& Dauksiene, E. (2013). Fostering Internationalisation in Higher Education by Virtual Mobility. Acta Technologica Dubnicae. doi:10.1515/atd2015-0015

Vriens, M., Petegem, W. Van, \& Achten, M. (2010). Virtual Mobility As an Alternative or Complement To Physical Mobility? In Edulearn 10 Proceedings. 2nd International Conference on Education and New Learning Technologies (pp. 6695-6702).

Wang, X., Su, Y., Cheung, S., Wong, E., \& Kwong, T. (2013). An exploration of Biggs' constructive alignment in course design and its impact on students' learning approaches. Assessment \& Evaluation in Higher Education, 38(4), 477-491. doi:10.1080/02602938.2012.658018

Wende, M. van der (Maria C. (1998). Virtual mobility: new technologies and the internationalization of higher education. Nuffic. 